\title{
Health Education Program for Children in Godog Village-Garut As A Preventive Effort to the COVID- 19 Virus
}

\author{
Nopi Rantika ${ }^{1, *}$, Shilpa Fitria A ${ }^{2}$, Kharisma Putri N ${ }^{3}$, Deska Syiami ${ }^{4}$, Dina Mulyani ${ }^{5}$ \\ ${ }^{112345}$ Jurusan Farmasi, Fakultas Matematika dan Ilmu Pengetahuan Alam, Universitas Garut, Jalan. \\ Jati No. 42B Garut 44151 \\ *E-mail: nopirantika@uniga.ac.id
}

\begin{abstract}
An epidemic of an acute respiratory disease called COVID-19 occurred at the end of 2019 in Wuhan (China) which spread throughout the world. COVID -19 can affect everyone from adults, the elderly, and children. So there needs to be education that is easy to carry out about Covid-19 and how to prevent it. This is the basis of the problem in encouraging community service activities so that they can be active in efforts to prevent COVID-19. The purpose of this educational activity is to prevent the spread of Covid-19 which is increasingly happening in Indonesia, so it is hoped that adults and children can take Covid-19 prevention. The method used during this activity is in the form of offline and online education to the surrounding community, where the material presented is in the form of proper handwashing and how to make hand sanitizers. As a result of the educational activities that have been carried out, there has been a significant change in the habits of the surrounding community where children can wash their hands properly and correctly, and for adults, especially local mothers can make hand sanitizers with the right natural ingredients to be used as emergency hand sanitizers. in daily activities.
\end{abstract}

Keyword: health, prevention, covid-19, children

\begin{abstract}
Abstrak
Wabah penyakit pernafasan atipikal akut yang disebut covid-19 terjadi pada akhir tahun 2019 di Wuhan (China) yang menyebar ke seluruh dunia. Covid -19 bisa menyerang semua orang mulai dari dewasa, lanjut usia dan anakanak. Sehingga perlu adanya edukasi yang mudah dipahami tentang Covid19 dan cara pencegahannya. Hal inilah yang menjadi dasar permasalahan dalam mendorong kegiatan pengabdian kepada masyarakat agar dapat berpartisipasi aktif dalam upaya pencegahan COVID-19. Tujuan dari kegiatan edukasi ini adalah untuk mencegah penyebaran Covid-19 yang semakin banyak terjadi di Indonesia, sehingga diharapkan orang dewasa dan anak-anak dapat melakukan upaya pencegahan Covid-19. Metode yang digunakan selama kegiatan ini berupa edukasi yang dilakukan secara offline maupun online kepada masyarakat sekitar, dimana materi yang disampaikan berupa cuci tangan yang benar serta cara membuat handanitizer. Akibat dari kegiatan edukasi yang telah dilakukan maka terjadi perubahan yang signifikan dari kebiasaan masyarakat sekitar dimana anak mampu mencuci tangan dengan baik dan benar, dan bagi orang dewasa khususnya ibu-ibu daerah dapat membuat handanitizer dengan bahan alami yang tepat untuk dapat digunakan sebagai hand sanitizer darurat dalam aktivitas sehari-hari.
\end{abstract}

Kata Kunci : kesehatan, pencegahan, covid-19, anak-anak

\section{Article Info:}

Received 01 Agustus 2020

Accepted 02 Agustus 2020

Available online 31 Agustus

2020

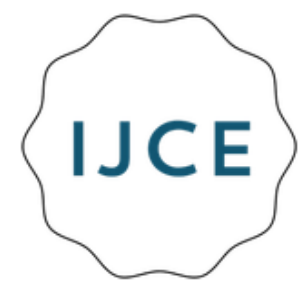




\section{PENDAHULUAN}

Akhir tahun 2019, wabah penyakit pernapasan atipikal akut terjadi di Wuhan, Cina. Penyakit ini dengan cepat menyebar dari Wuhan ke daerah lain. Penelitian menunjukkan bahwa coronavirus. Sindrom gangguan pernapasan akut disebabkan oleh coronavirus. Organisasi Kesehatan Dunia (WHO) menamainya sebagai SARS-CoV-2 atau 2019-nCoV), karena tingginya angka terhadap infeksi oleh virus ini WHO menyatakan sebagai epidemic Covid-19 ${ }^{1}$. Wabah SARS-CoV-2 dianggap berawal melalui transmisi zoonosis yang terkait dengan pasar makanan laut di Wuhan,Cina. Kemudian transmisi dari manusia ke manusia memainkan peran utama dalam penyebaran berikutnya ${ }^{2}$. COVID-19 telah berdampak pada sejumlah besar orang di seluruh dunia, dilaporkan di sekitar 200 negara dan wilayah ${ }^{3}$. Pada 7 April 2020, sekitar 1.400.000 kasus di seluruh dunia telah dilaporkan ${ }^{1}$.

Gejala utama terkait penyakit ini, diantaranya demam, batuk kering dan dyspnea ${ }^{4}$. Gejala tambahan, seperti sakit kepala, pusing, badan lemas, muntah dan diare ${ }^{5}$. Sekarang diakui secara luas bahwa gejala pernapasan. Waktu timbulnya gejala biasanya terjadi setelah 9 hari, kemudian menunjukkan gejala pernapasan yang dapat berkembang pesat. Studi epidemiologi telah menunjukkan bahwa penyakit ini menyebabkan kematian lebih tinggi pada populasi usia tua, pada orang yang mempunya penyakit yang mendasari dan pada anak-anak ${ }^{1}$.

Pusat Pengendalian dan Pencegahan Penyakit Amerika Serikat [CDC AS] pada tanggal 2 April 2020, menyatakan bahwa 1,7\% pasien yang terinfeksi virus covid-19 adalah pasien dengan usia lebih muda dari 18 tahun dan 22\% anak-anak dengan usia 18 tahun. Meskipun COVID-19 tidak parah terjadi pada anak-anak, bayi dengan kondisi yang mendasarinya harus dipantau untuk perkembangan penyakit. Manifestasi klinis mungkin lebih ringan pada anakanak daripada pada orang dewasa dengan beberapa gejala pernapasan atas seperti hidung tersumbat dan rhinorrhea. Prognosis baik pada anak-anak, dan kebanyakan dari mereka pulih setelah satu sampai dua minggu. Infeksi parah pada anak-anak dapat menunjukkan tachypnea dengan laju pernapasan $\geq 30$ kali / menit, saturasi oksigen kurang dari 93\% dalam situasi istirahat, dan tekanan parsial arteri oksigen $(\mathrm{PaO} 2) /$ konsentrasi oksigen $(\mathrm{FiO} 2) \leq 300 \mathrm{mmHg}$. Keadaan kritis pada anak-anak didefinisikan sebagai kegagalan pernapasan, syok septik, dan kegagalan organ lainnya ${ }^{6}$.

Pencegahan virus COVID-19 yang telah diterapkan oleh pemerintah, diantaranya seperti gerakan mencuci tangan atau penggunaan hand snatizer dan penggunaan masker. Pemberian edukasi dan menjaga kesehatan diri merupakan hal yang penting diterapkan, terutama pada anak-anak usia dini. Anak-anak usia dini rawan terkena penyakit, yang disebabkan karena daya tahan mereka belum sekuat orang dewasa pada umumnya. Anak-anak juga memiliki kebiasaan memasukkan tangan kedalam mulut mereka, tanpa memperhatikan apa yang mereka pegang sebelumnya. Periku ini menjadi bahaya, apabila anak-anak tidak diajarkan berperilaku hidup sehat ${ }^{7}$.

Dengan demikian, melalui kegiatan pengabdian masyarakat di masa pandemic ini kami melakukan beberapa program edukasi kesehatan kepada anak-anak, seperti pemberian informasi mengenai covid-19 dan bahaya nya, gerakan cuci tangan serta pembagian madu pada anak-anak usia dini di Desa Godog, Kecamatan Karangpawitan, Kabupaten Garut guna mencegah dan memutus rantai penyebaran covid-19. 


\section{METODE}

Pengabdian masyarakat dilakukan dengan memberikan pemahaman dan informasi mengenai covid-19 melalui media visual (menggunakan leflet/brosur dan video pembelajaran) dan beberapa kegiatan yang dilakukan secara langsung.

\section{Tahap Persiapan}

Melakukan kunjungan lokasi dan wawancara kepada Kepala Desa guna mencari tahu profil Desa Godog, Kecamatan Karangpawitan, Kabupaten Garut, Provinsi Jawa Barat. Serta melakukan penyiapan sarana dan prasarana yang akan digunakan dalam melaksanakan kegiatan pengabdian masyarakat.

\section{Tahap Pelaksanaan}

Program edukasi kesehatan di masa pandemi COVID-19 dilakukan dengan membuat leflet/brosur dan video pembelajaran tentang covid-19 yang mudah dipahami, mudah dibaca dan menarik untuk anak-anak. Selain itu, kami melakukan kegiatan secara langsung melalui gerakan mencuci tangan, dan pembagian madu pada anak-anak Desa Godog, Kecamatan Karangpawitan, Kabupaten Garut.

3. Tahap Evaluasi pelaksanaan

Tahap evaluasi pelaksanaan program di lapangan setelah kegiatan ini selesai dilaksanakan adalah dengan terus membangun komunikasi dan dan memberikan informasi-informasi yang penting kepada masyarakat, baik kepada Kepala Desa setempat, keluarga dan khususnya anak-anak Desa Godog, Kecamatan Karangpawitan, Kabupaten Garut, Provinsi Jawa Barat.

\section{HASIL DAN PEMBAHASAN}

Kegiatan utama dalam program edukasi kesehatan terkait pencegahan penyebaran virus covid-19 adalah memberikan edukasi dan demostrasi seputar covid-19 kepada anak-anak Desa Godog. Setiap kegiatan yang dilakukan offline selalu menggunakan protocol kesehatan yang ketat, seperti pada Gambar 1.

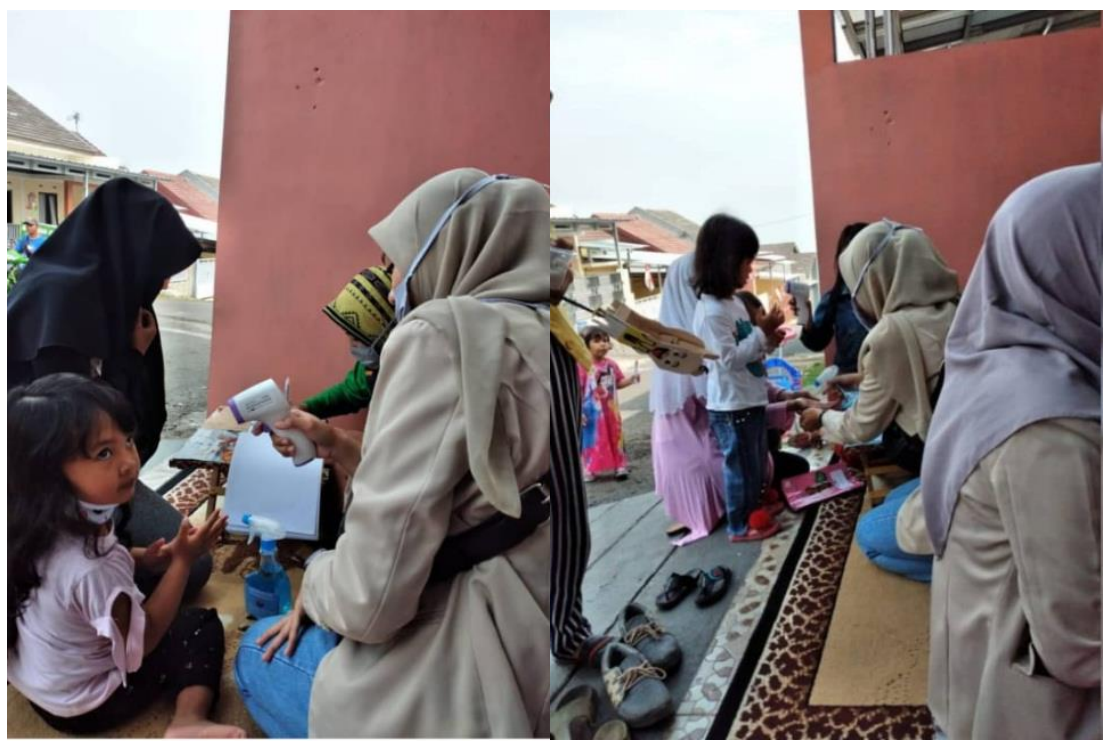

Gambar 1. Penerapan Protokol Kesehatan pada Anak-anak Desa Godog, Kecamatan Karangpawitan Garut

Kegiatan sosialisasi ini dilakukan pada bulan Agustus 2020 bertempat di Desa Godog. Peserta pada kegiatan ini adalah anak-anak usia dini RT 03/RW 19 di Desa Godog, Kecamatan 
Karangpawitan, Kabupaten Garut, Provinsi Jawa Barat. Kegiatan awal, melakukan sosialisasi pencegahan Covid-19 dengan cara menempelkan poster/leflet mengenai informasi Covid-19 di ruang publik, seperti posyandu, masjid dll (Gambar 2). Selanjutnya, kegiatan edukasi dan demonstrasi pencegahan covid-19 secara offline kepada anak-anak usia dini Desa Godog (Gambar 3). Tak hanya itu, edukasi dan demontrasi secara online juga dilakukan melalui media social yang dibagikan kepada masyarakat terutama orang tua, sehingga pemahaman tentang Covid-19 dapat didukung oleh masing-masing orang tua.

Selain orang tua,anak-anak juga perlu mendapatkan informasi yang mudah dipahami agar dapat melaksanakan beragam pencegahan covid-19 yang telah dirancang oleh pemerintah.salah satu media yang disukai anak-anak adalah media bergambar.media tersebut mudah dipahami dan lebih diminati di kalangan anak-anak terutama sekolah dasar. Media gambar dapat menginspirasi pemikiran anak-anak untuk memahami materi ${ }^{8}$.

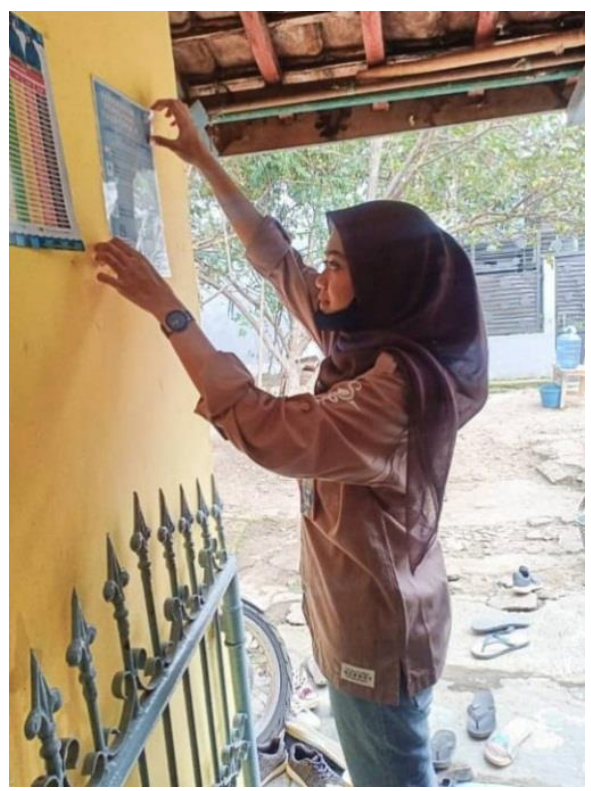

Gambar 2. Penempelan leaflet/brosur tentang covid 19 di ruang publik Desa Godog, Kecamatan Karngpawitan Garut.

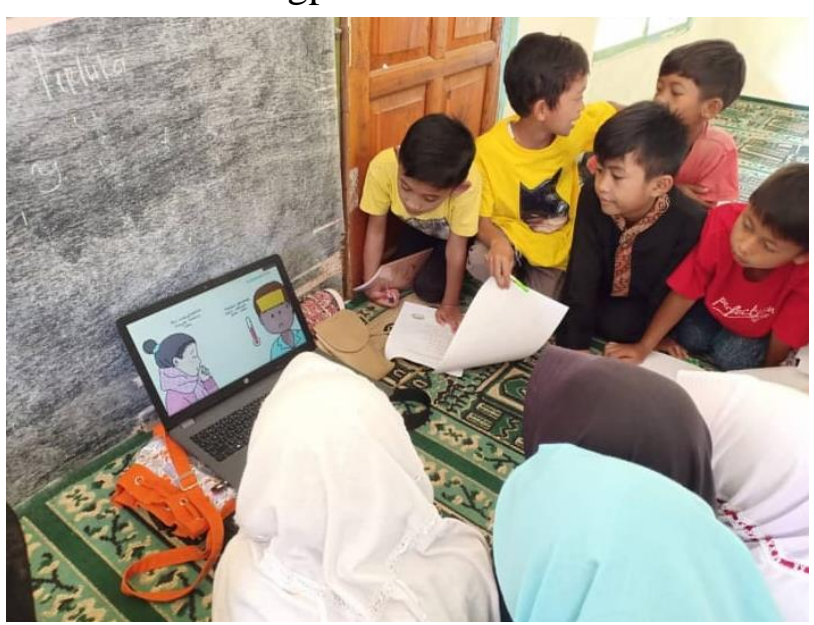

Gambar 3. Pemberian Edukasi tentang covid 19 menggunakan video menarik kepada anakanak Desa Godog, Kecamatan Karngpawitan Garut.

Mencuci tangan merupakan perilaku sederhana yang penting untuk kebiasaan kehidupan sehari-hari. Tangan merupakan salah satu tempat utama masuknya mikroba yang menyebabkan penyakit dari mulut ke hidung dan anggota tubuh lainnya. Penyebaran mikroba tersebut melalui 
makanan dan minuman atau benda-benda yang menempel ditangan baik secara sengaja maupun tidak sengaja. Tangan juga sebagai sumber penyebaran kuman dari satu orang ke orang lainnya.Cukup banyak masalah kesehatan dapat di timbulkan dari kebiasaan cuci tangan ${ }^{9}$

Cara mencuci tangan yang baik dan benar yaitu gosok kedua telapak tangan, gosokkan punggung dan sela-sela jari tangan kiri dan tangan kanan, gosokkan kedua telapak tangan dan sela-sela jari, jari-jari sisi dalam dari kedua tangan saling mengunci, gosokkan ibu jari kiri berputar dalam genggaman tangan kanan dan lakukan sebaliknya, gosokkan dengan memutar ujung jari-jari tangan kanan ditelapak tangan kiri dan sebaliknya, kemudian keringkan tangan menggunakan tissue atau handuk. (Gambar 4)

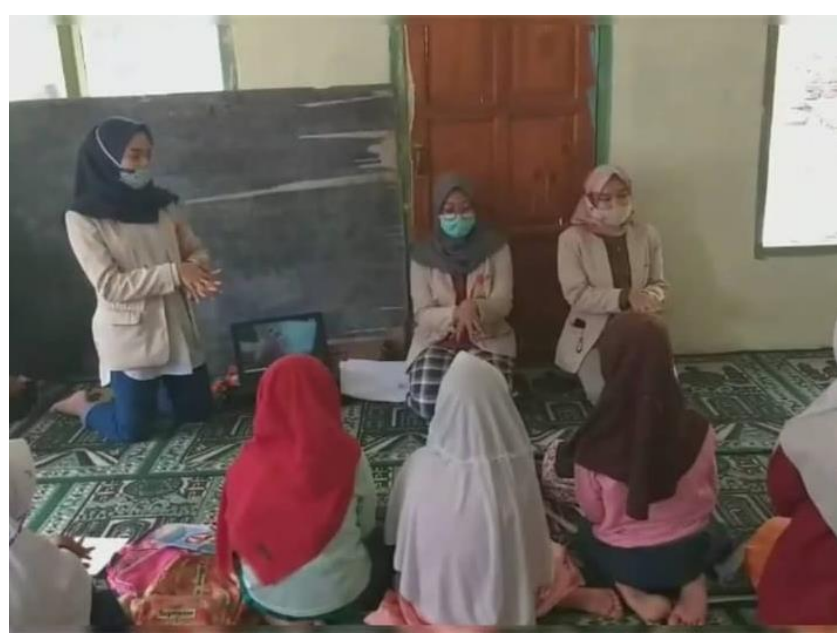

Gambar 4. Pemberian Edukasi tentang cuci tangan kepada anak-anak Desa Godog, Kecamatan Karngpawitan Garut.

Berdasarkan program yang kami telah lakukan bahwa sebelum diberikan edukasi didapatkan sebesar 26\% dari 15 anak yang sudah bisa melakukan cuci tangan yang baik dan benar kemudian setelah diberikan edukasi melalui video yang kami berikan didapatkan hasil sebesar $100 \%$ dimana semua anak sudah bisa melakukan kegiatan cuci tangan yang baik dan benar.

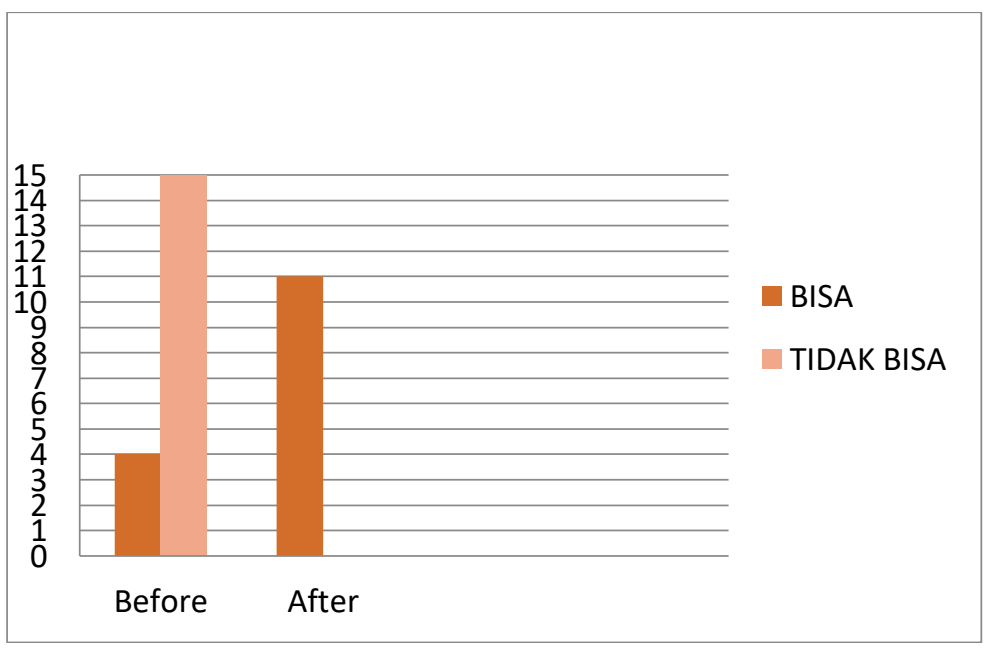

Gambar 5. Diagram Hasil Pretest dan Posttest Edukasi Cuci Tangan menarik kepada anak-anak Desa Godog, Kecamatan Karngpawitan Garut. 
Dalam upaya program edukasi kesahatan terhadap anaka-anak ,kami membagi kan madu sebagaimana Madu memiliki banyak khasiat salah satunya sebagai antioksidan yang memiliki senyawa flavonoid sebagai imunodulator yang dapat meningkatkan sistem kekebalan tubuh terhadap infeksi penyakit,luka dan radikal bebas. ${ }^{10}$

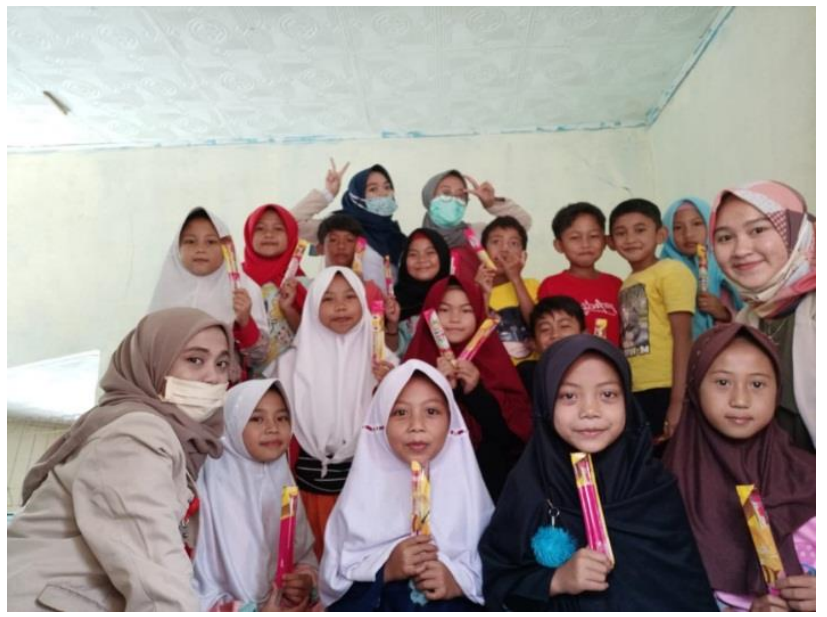

Gambar 6. Pemberian madu kepada anak-anak Desa Godog, Kecamatan Karngpawitan Garut.

\section{KESIMPULAN DAN SARAN}

Berdasarkan kegiatan sosialisasi yang telah dilakukan terkait program edukasi kesehatan dalam mencegah covid-19 pada Desa Godog ini dapat disimpulkan bahwa kegiatan ini dapat berjalan dengan baik dan lancar. Masyarakat dan anak-anak sangat antusias dan dapat bekerjasama dengan baik, serta mereka dapat memahami segala kegiatan yang telah diberikan guna memutus rantai penyebaran covid-19. Adapun perubahan signifikan yang terjadi dimana beberpa masyarakat telah mengetahui cara membuat handsanitizer yang baik dan benar hal lain yang telah dilakukan kuliah kerja nyata ini adalah anak-anak yang berada dibawah umur sudah bias melakukan proses cuci tangan yang baik dan benar sesuai anjuran para ahli medis. Diharapkan untuk kegiatan selanjutnya proses menyampaian materi dapat dilakukan dengan lebih maksimal jika masyarakat yang terlibat dapat di edukasi secara langsung ataupun tidak langsung menggunakan perangkat yang memadai.

\section{REFERENSI}

[1]. Yuki K, Fujiogi M, Koutsogiannaki S. COVID-19 pathophysiology: A review. Clin Immunol. 2020;215. doi:10.1016/j.clim.2020.108427

[2] Li Q, Guan X, Wu P, et al. Early transmission dynamics in Wuhan, China, of novel coronavirus-infected pneumonia. $N$ Engl J Med. 2020;382(13):1199-1207. doi:10.1056/NEJMoa2001316

[3] Zheng M, Gao Y, Wang G, et al. Functional exhaustion of antiviral lymphocytes in COVID-19 patients. Cell Mol Immunol. 2020;17(5):533-535. doi:10.1038/s41423-020$0402-2$

[4] Huang C, Wang Y, Li X, et al. Clinical features of patients infected with 2019 novel coronavirus in Wuhan, China. Lancet. 2020;395(10223):497-506. doi:10.1016/S01406736(20)30183-5

[5] Shi H, Han X, Jiang N, et al. Radiological findings from 81 patients with COVID-19 
pneumonia in Wuhan, China: a descriptive study. Lancet Infect Dis. 2020;20(4):425434. doi:10.1016/S1473-3099(20)30086-4

[6] Khoshnevisasl P, Sadeghzadeh M, Sadeghzadeh S. A Review of COVID-19 in Children. J Compr Pediatr. 2020;11(3). doi:10.5812/compreped.103780

[7] Tabi'in A. Perilaku Hidup Bersih Dan Sehat (PHBS) pada Anak Usia Dini Sebagai Upaya Pencegahan COVID 19. JEA (Jurnal Edukasi AUD). 2020;6(1):58. doi:10.18592/jea.v6i1.3620

[8] Sari MK. Sosialisasi Tentang Pencegahan Covid-19 di Kalangan Siswa Sekolah Dasar di SD Minggiran 2 Kecamatan Papar Kabupaten Kedir. J Karya Abadi. 2020;4:80-83. doi:10.1017/CBO9781107415324.004

[9] Meijer A. latar belakang mencuci tangan. Экономика Региона. 2013;2012(August):32.

[10] Handayani E. Skrining Kandungan Senyawa Aktif Madu Dan Uji Potensinya Sebagai Antioksidab. Skripsi, Univ Hasanudin Makassar. 2018:7-9. 